\title{
Penerapan Undang-Undang Kepailitan dalam Menciptakan Iklim Berusaha Yang Sehat Bagi Seluruh Pelaku Usaha
}

\author{
Syafrudin Makmur \\ Fakultas Syariah dan Hukum UIN Syarif Hidayatullah, Jakarta \\ Email : syafrudin@uinjkt.ac.id
}

\begin{abstract}
Law Number 37 Year 2004 concerning Bankruptcy and Postponement of Debt Payment Obligation (PKPU) is enacted in good faith to protect the rights of creditors who have receivables on the insolvent party, since in general the assets left by the insolvent party is less than the amount of the debt. So that the condition is very potential to cause chaos if the number of creditors more than one, because they each will fight each other to control the assets left behind as compensation for the settlement of receivables, and eventually among the creditors will apply: "who fast/strong he can, and who is slow / weak he bit the finger". With the stipulation of bankruptcy provisions in this law, congruent lenders will no longer fight each other because each will get the compensation of debt repayment proportionally according to the principle of "pari pasu pro rata parte".
\end{abstract}

Keywords : Proper Application of Bankruptcy Law

Undang Undang Nomor 37 Tahun 2004 tentang Kepailitan dan Penundaan Kewajiban Pembayaran Utang (PKPU) diundangkan dengan itikad untuk melindungi hak-hak para kreditur yang memiliki piutang pada pihak yang pailit, mengingat pada umumnya aset yang ditinggalkan oleh pihak yang pailit jumlahnya lebih kecil daripada jumlah hutangnya. Sehingga kondisi tersebut sangat berpotensi untuk menimbulkan kekacauan apabila jumlah kreditur lebih dari satu, karena mereka masing-masing akan saling berebut untuk menguasai aset yang ditinggalkan sebagai kompensasi pelunasan piutangnya, dan pada akhirnya diantara para kreditur akan berlaku: "siapa cepat/kuat dia dapat, dan siapa lambat/lemah dia gigit jari". Dengan diaturnya ketentuan pailit dalam undang-undang ini, maka para kreditur kongruen tidak akan lagi saling berebut karena masing-masing akan mendapatkan kompensasi pelunasan hutangnya secara proporsional sesuai prinsip "pari pasu pro rata parte".

Kata Kunci : Penerapan Undang-Undang Kepailitan Secara Benar.

\section{PENDAHULUAN}

Krisis ekonomi yang terjadi di Indonesia telah memberi pengaruh tidak menguntungkan terhadap perekonomian nasional sehingga menimbulkan kesulitan besar terhadap dunia usaha dalam menyelesaikan utang piutang untuk meneruskan kegiatannya dan menimbulkan dampak yang merugikan masyarakat. Sementara itu ada tuntutan yang mendesak dari berbagai pihak agar perlunya perubahan Undang-Undang Kepailitan yang lebih melindungi kepentingan dunia usaha. ${ }^{1}$ Krisis moneter pada tahun 1997 berdampak perekonomian nasional menimbulkan kesulitan terhadap dunia usaha bahkan kesulitan dalam penyelesaian hutang piutang. Selanjutnya tidak sedikit dunia usaha yang gulung tikar sedangkan yang masih dapat bertahanpun hidupnya menderita. ${ }^{2}$

\footnotetext{
${ }^{1}$ Zainal Asikin, Hukum Kepailitan Dan Penundaan Kewajiban Pembayaran Utang Di Indonesia, Pustaka Reka Cipta, Bandung, 2013, hlm. 10.

${ }^{2}$ Gunawan Widjaya, "Risiko Hukum \& Bisnis Perusahaan Pailit", Majalah Forum Sahabat, 2000, hlm. 1.
} 
Untuk mengatasi hal tersebut Pemerintah Republik Indonesia pada tanggal 24 April 1998 telah mengeluarkan Peraturan Pemerintah Pengganti Undang Undang atau Perpu Nomor 1 tahun 1998 tentang Perubahan atas Undang Undang Kepailitan, yang kemudian disahkan menjadi Undang undang Nomor 4 tahun 1998 Tentang Kepailitan dan Penundaan Kewajiban Pembayaran Utang, pada tanggal 24 Juli 1998 yang merupakan penyempurnaan dari Faillissement Verordening Staatsblad tahun 1905 Nomor 217 Jo. Staatsblad tahun 1906 Nomor 834.

Kepailitan dan Penundaan Kewajiban Pembayaran Utang (PKPU) adalah merupakan salah instrument hukum yang diataur undang-undang dalam rangka menyelesaiakan permasalah utang-piutang yang melilit diantara antara kreditor dan debitor. Pada dasamya kepailitan dan PKPU adalah merupakan tindak lanjut dari prinsip paritas creditoroum dan prinsip pari passu prorle parte pada sistem hukum harta kekayaan yang diatur dalam ketentuan Pasal 1131 dan Pasal 1332 Kitab Undang-Undang Hukum Perdata. Pasal 1131 berbunyi : "Segala barang-barang bergerak dan tak bergerak milik debitur, baik yang sudah ada maupun yang akan ada, menjadi jaminan untuk perikatan-perikatan perorangan debitur itu", sedangkan Pasal 1332, berbuyi : "Hanya barang yang dapat diperdagangkan saja yang dapat menjadi pokok persetujuan". 3

Prinsip paritas creditoroum (kesetaraan kedudukan para kreditur) menentukan bahwa para kreditur memperoleh hak yang sama terhadap semua harta benda debitur. Apabila debitur tidak dapa membayar utangnya maka harta kekayaan debitur menjadi sasaran kreditur. Prinsip paritas creditoroum mengandung makna bahwa semua kekayaan debitur baik yang berupa barang bergerak ataupun barang tidak bergerak maupun harta yang sekarang telah dipuyai debitur dan barang-barang dikemudian hari akan dimiliki

\footnotetext{
${ }^{3}$ Kitab Undang-Undang Hukum Perdata (Burgerlijk Wetboek Voor Indonesie), Staatsblad Tahun 1847 Nomor 23.
}

debitur terikat kepada penyelesaian kewajiban debitur. ${ }^{4}$ Prinsip paritas creditoroum diatur dalam ketentuan Pasal 1131 Kitab UndangUndang Hukum Perdata yang berbunyi :5 "Segala kebendaan si berutang, baik yang bergerak maupun yang tak bergerak, baik yang sudah ada maupun yang baru akan ada dikemudian hari, menjadi tanggungan untuk segala perikatan perseorang".

Sedangkan kepailitan untuk bukan pedagang (pengusaha) diatur dalam Reglement op de Rechtsvordering atau disingkat Rv (Staatsblad 1847-52 jo. 184963), Buku Ketiga, Bab Ketujuh, yang berjudul Tan den Staw van Kennelijk Onvermorgen (Tentang Keadaan Nyata-nyata Tidak Mampu), dalam Pasal 899 sampai dengan Pasal 915, yang kemudian telah di cabut oleh Staatsblad 1906-348. ${ }^{6}$

Pada era di atas, terdapat dua buah peraturan yang mengatur tentang hukum kepailitan yang masing untuk para pedagang dan bukan pendagang (perorangan). Dengan dua peraturan seperti ini sudah barang tentu terasa menyulitkan. Karena adanya kesulitankesulitan tersebut maka timbul keinginan membuat peraturan kepailitan yang sederhana dengan biaya yang tidak banyak, agar memudahkan dalam pelaksanaannya. Sehubungan dengan maksud tersebut, maka pada tahun 1905 diundangkan Faillisement verordering (Staatsblad 1905 No. 207 jo Staatsblad 1906 No. 348). Peraturan ini lengkapnya bernama Verordening op het Faillessement en de Surseance van Betaking voor de Europeanen in Nederland Indie (Peraturan Untuk Kepailitan Dan Penundaan Pembayaran Untuk Orang-Orang Eropa). Berdasarkan Verordening ter invoering van

\footnotetext{
${ }^{4}$ M. Hadi Shubhan, Hukum Kepailitan, Prinsip, Norma dan Praktik Di Pengadilan, Prenadamedia, Jakarta, 2008, hlm. 27-28.

${ }^{5}$ R.Subekti, R. Tjitrosudibio, Kitab Undang-Undang Hukum Perdata, PT. Pradnya Paramita, Jakarta, 2005, hlm. 191.

${ }^{6}$ Sutan Remy Sjahdeini, Hukum Kepailitan, Memahami Faillissemensverordening Juncto Undang-undang No. 4 Tahun 1998, PT. Pustaka Utama Grafiti, Jakarta, 1998, hlm. 25.
} 
de faillissement verordening (Staatsblad 1905-217) itu dinyatakan mulai berlaku pada tanggal 1 Nopember $1906 .^{7}$

Meskipun pada dasarnya diperuntukan sebagai salah satu instrument bagi para pedagang (kaum pengusaha) dalam upaya menyelesaikan hutang piutang, namun dalam praktek, faillissementverordening ini relatif sangat sedikit digunakan. Hal ini selain kurang dikenal di tengah-tengah masyarakat, karena memang sejak awal diperuntukan bagi pedagang yang tunduk pada hukum perdata dan dagang barat, juga karena sebagian besar pedagang atau pengusaha pribumi Indonesia adalah terdiri dari pedagang atau pengusaha kecil dan menengah yang tidak banyak melakukan transaksi besar, sehingga penyelesaian hutang-piutang melalui mekanisme kepailitan yang diatur dalam faillissementverordening menjadi tidak popular.

Selain kedua alasan di atas, ternyata keenganan perusahaan maupun pedagang, menempuh mekanisme kepailitan juga dikarenakan prosedur yang diatur dalam ketentuan faillissementverordenin, dianggap cenderung lama dan bertele-tele. Hal ini dapat dimaklumi karena pada kenyataannya dalam hal beracara di pengadilan faillissementverordening masih mengacu kepada prosedur hukum acara perdata umum yang selain memakan waktu cukup lama juga membutuhkan biaya yang tidak sedikit. ${ }^{8}$

Faktor lain yang tidak kalah rendahnya tingkat kepercayaan masyarakat pada kemampuan lembaga pengadilan yang disangksikan untuk dapat bersikap objektif atau tidak memihak dan akan sungguhsungguh menegakan keadilan. Karena persepsi masyarakat yang negatif terhadap badan peradilan, maka masyrakat merasa

\footnotetext{
${ }^{7}$ Ibid, hlm. 26.

${ }^{8}$ Sesuai dengan ketentuan hukum acara perdata umum, maka prosedur pemeriksaan ditingkat pengadilan negeri akan memakan waktu cukup lama dan kemudian masih dimungkin untuk naik banding ketingkat Pengadilan Tinggj serta Kasasi ketingkat Mahkamah Agung.
}

tidak ada sarana yang efektif yang dapat digunakan Kreditor untuk dapat melindungi kepentingannya, khususnya agar Debitor yang nakal dapat melunasi kewajibannya, jika perlu dengan melakukan paksaan secara hukum melalui pengadilan.

Sutau penjelasan yang lain adalah bahwa para kreditor kurang mempercayai sistem peradilan di Indonesia, yang mengkhawatirkan bahwa debitor dapat mempunyai akses yang lebih mudah di Pengadilan untuk mempertahankan kasus mereka, walaupun mereka tidak mempunyai dasar argumentasi yang kuat. Diantara kreditor asing sering ada perasaan bahwa mereka bermain suatu "away game" di Indonesia dan bahwa mereka akan keluar sebagai nomor dua tanpa memperdulikan bobot tagihan mereka.

Berdasarkan alasan tersebut, kreditur asing ingin menghindari untuk berperkara di pengadilan dan lebih memilih untuk mengadakan penyelesaian damai di luar pengadilan. Mereka mempunyai sedikit kewenangan untuk melakukan negosisasi dengan debitur yang telah melakukan defult. Ancaman untuk mengajukan permohonan pailit ke Pengadilan hanyalah upaya gertakan kreditur yang tidak berdaya. Kreditur asing menganggap bahwa mengajukan suatu permohonan kepailitan bukan suatu cara yang realistis untuk menyelesaikan suatu masalah di Indonesia. ${ }^{9}$

Seiring dengan terjadinya krisis moneter yang melanda sebagian besar wilayah dunia, Indonesia juga tidak luput dari imbasnya yang berakibat langsung pada ketidakmampuan para pengusaha/perusahaan membayar utangnya dengan tepat waktu. Dalam kodisi ini maka dirasa perlu dan mendesak untuk dilakukan perbaikan (perubahan) terhadap peraturan hukum kepailitan dan PKPU, karena dengan masih tetap menggunakan ketentuan faillissementverordenin dianggap kurang

\footnotetext{
${ }^{9}$ Jerry Hoff, Undang-Undang Kepailitan Di Indonesia, Penterjernah Kartini MuIjadi, PT. Tatanusa, Jakarta, 2000, hlrn. 2-3
} 
mampu memenuhi kebutuhkan para pencari keadilan dalam menyelesaian masalah hutang piutang yang terjadi pada saat itu. Hal ini tentu dapat dimaklumi karena secara faktual faillissementverordening Stb.1905 Nomor 217 jo Stb.1906 Nomor 348, sudah banyak yang tidak sesuai lagi dengan perkembangan mengingat usia peraturan perundangundangan ini sudah hampir satu abad. ${ }^{10}$

Atas dasar hal tersebut di atas serta desakan Dana Moneter Internasional/Internasional Monetery Fund (IMF), maka pada tanggal 22 April 1998 diterbitkanlah Peraturan Pemerintah Pengganti Undangan-Undang No. I Tahun 2008 yang kemudian pada tanggal 9 September 1998 diundangkan menjadi Undang-Undang No. 4 Tahun 2008, tentang Penetapan Peraturan Pemerintah Pengganti Undang-Undang No. I tahun 2008 menjadi Undang-Undang. Pada dasarnya UndangUndang No. 4 tahun 1998 ini bukanlah Undang-Undang Kepailitan yang baru melaingkan hanya sekedar mengubah dan menambah faillissementverordening Staatsblad 1905 Nomor 217 jo Staatsblad 1906 Nomor 348 . faillissementverordening terdiri dari 279 pasal, sedangkan UndangUndang No. 4 Tahun 1998 mencabut 6 pasal (Pasal 14A, 19, 218, 219, 221 dan 272 dan 1 ayat (Pasal 149 ayat (3). Terdapat 93 pasal yang diubah dan menambah 10 pasal baru. Dengan demikian pasal Undang-Undang No. 4 Tahun 1998 adalah 282 pasal. $^{11}$

Hukum kepailitan dan PKPU telah menjelma menjadi fenomena tersendiri dalam sejarah hukum di Indonesia, Kepailitan dan PKPU yang tadinya nyaris tidak pernah dilirik oleh praktisi hukum, dalam waktu singkat mengalami lonjakan permohonan. Dalam tiga tahun pertama, Pengadilan Niaga Jakarta Pusat rata-rata menerima 72 permohonan tiap tahunnya. Hanya dalam tiga bulan operasi Pengadilan Niaga Jakarta Pusat telah

\footnotetext{
${ }^{10}$ H. Man S. Sastrawidjaja, Hukum Kapailitan Dan Pendundaan Kewajiban Pembayaran Utang, PT. Alumni, Bandung, 2006, hlm. 14.

${ }^{11}$ Sutan Remy Syahdeni, op.cit, hlm. 29.
}

menerima 31 permohanan Pailit, tahun kedua jumlah tersebut meningkat menjadi 100 pemohon. ${ }^{12}$

Seiring dengan perkembangan peradaban manusia berkembang pula perkembangan hukum dan ekonomi. Hukum adalah peraturan-peraturan yang bersifat memaksa, yakni peraturan-peraturan yang dibuat oleh badan-badan resmi yang berwajib. Pelanggaran terhadap peraturan-peraturan tadi berakibat diambilnya tindakan yaitu dengan hukuman tertentu. ${ }^{13}$

Kepastian hukum merupakan pertanyaan yang hanya bisa dijawab secara normatif, bukan sosiologis. Kepastian hukum secara normatif adalah ketika suatu peraturan dibuat dan diundangkan secara pasti karena mengatur secara jelas dan logis. Jelas dalam artian tidak menimbulkan keragu-raguan (multi-tafsir) dan logis dalam artian ia menjadi suatu sistem norma dengan norma lain sehingga tidak berbenturan atau menimbulkan konflik norma. Konflik norma yang ditimbulkan dari ketidakpastian aturan dapat berbentuk kontestasi norma, reduksi norma atau distorsi norma. Pemikiran mainstream beranggapan bahwa kepastian hukum merupakan keadaan dimana perilaku manusia, baik individu, kelompok, maupun organisasi, terikat dan berada dalam koridor yang sudah digariskan oleh aturan hukum. Secara etis, pandangan seperti ini lahir dari kekhawatiran yang dahulu kala pernah dilontarkan oleh Thomas Hobbes bahwa manusia adalah serigala bagi manusia lainnya (homo hominilupus). ${ }^{14}$

Manusia adalah makhluk yang beringas yang merupakan suatu ancaman. Untuk itu, hukum lahir sebagai suatu pedoman untuk menghindari jatuhnya korban. Konsekuensi

\footnotetext{
${ }^{12}$ Aria Suyudi, Eryanto Nugroho, Herni Sri Nurbayanti, Kepailitan di Negara Pailit, Pusat Studi Hukum \& Kebijakan Indonesia, Jakarta, 2003, hlm. 21.

${ }^{13}$ C.S.T Kansil, dan Cristine S.T, Hukum Perusahaan Indonesia Bag 1, Pradnya Paramita, Jakarta, 2005, hlm. 56.

14“"Apa Itu Kepastian Hukum”, http://yancearizona.wordpress.com, diakses tanggal 10 September 2017.
} 
dari pandangan ini adalah bahwa perilaku manusia secara sosiologis merupakan refleksi dari perilaku yang dibayangkan dalam pikiran pembuat aturan. ${ }^{15}$

Negara dan bangsa Indonesia pun menghendaki adanya tatanan masyarakat yang tertib, tenteram, damai dan seimbang, sehingga setiap konflik, sengketa atau pelanggaran diharapkan untuk dipecahkan atau diselesaikan: hukum harus ditegakkan, setiap pelanggaran hukum harus secara konsisten ditindak, dikenai sanksi. Kalau setiap pelanggaran hukum ditindak secara konsisten maka akan timbul rasa aman dan damai, karena ada jaminan kepastian hukum.

Lembaga Pengadilan menurut Anton Reinhart, ${ }^{16}$ yaitu memberi pelayanan hukum, perlindungan hukum dan keadilan. Menurut M. Yahya Harahap, ${ }^{17}$ bahwa keberadaan peradilan dibutuhkan dengan alasan : Peradilan masih tetap diharapkan berperan sebagai "the last resort" sebagai tempat terakhir mencari kebenaran dan keadilan, sehingga pengadilan masih diandalkan sebagai badan yang berfungsi menegakan kebenaran dan keadilan (to enforce the truth and to enforce justice).

Sistem pemerintahan negara yang telah dipertegaskan di dalam penjelasan UndangUndang Dasar 1945 menyatakan antara lain bahwa Indonesaia adalah Negara yang berdasarkan atas hukum (rechstaat) dan tidak berdasarkan atas kekuasaan belaka (machtstaat). Hal ini mengandung makna bahwa dinegara yang berdasarkan atas hukum, hukum harus menampilkan peranannya secara mendasar sebagai titik sentral dalam seluruh kehidupan orang-

\footnotetext{
15 Ibid.

${ }^{16}$ Anton Reinhard, Masalah Hukum (dari Katalog Sampai Kwitansi), Cet. 1, Aksara Persada, Jakarta, 1985, hlm. 103.

${ }^{17}$ M. Yahya Harahap, Beberapa Tinjauan Mengenai Sistim Peradilan dan Penyelesaian Sengketa, Cet. 1. Citra Aditya Bakti, Jakarta, 1997, hlm. 237.
}

perorangan, kehidupan masyarakat, maupun kehidupan berbangsa dan bernegara. ${ }^{18}$

Indonesia merupakan suatu negara hukum dimana kekuasaan tunduk pada hukum. Sebagai negara hukum, maka hukum mempunyai kedudukan paling tinggi dalam pemerintahan, hukum adalah perlindungan kepentingan manusia. Hukum mengatur segala hubungan antar individu atau perorangan dan individu dengan kelompok atau masyarakat maupun individu dengan pemerintah.

Prinsip negara hukum menjamin kepastian, ketertiban, dan perlindungan hukum yang berintikan kebenaran dan keadilan. Kepastian, ketertiban dan perlindungan hukum menuntut antara lain bahwa lalu lintas hukum dalam kehidupan masyarakat memerlukan adanya alat bukti yang menentukan dengan jelas hak dan kewajiban seseorang sebagai subyek hukum dalam masyarakat.

Konsep di atas menunjukkan adanya kompromi antara hukum yang bersifat tertulis sebagai suatu kebutuhan masyarakat hukum demi kepastian hukum dan living law sebagai wujud dari pembentukan dari pentingnya peranan masyarakat dalam pembentukan dan orientasi hukum. ${ }^{19}$ Aktualisasi dari living law tersebut bahwa hukum tidak dilihat dalam wujud kaidah melainkan perkembangannya dalam masyarakat itu sendiri.

Hukum merupakan kontrol sosial yang dilakukan oleh pemerintah. Dengan perkataan lain, kontrol sosial merupakan kehidupan normatif sari suatu negara beserta warga negaranya. ${ }^{20}$ Negara dan bangsa Indonesia pun menghendaki adanya tatanan masyarakat yang tertib, tenteram, damai dan seimbang, sehingga setiap konflik, sengketa atau

18 Mulyana W. Kusumah, Perspektif, Teori dan Kebijaksanaan Hukum, Rajawali, Jakarta, 1986, hlm. 29.

${ }^{19}$ Lili Rasjidi dan Putra. I. B. Wiyasa, Hukum Sebagai Suatu Sistem, Remaja Rosdakarya, Bandung, 2005, hlm. 79.

${ }^{20}$ Rony Hanitijo Soemitro, Beberapa Masalah Dalam Studi Hukum Dan Masyarakat, Remadja Karya, Bandung, 1985, hlm. 91. 
pelanggaran diharapkan untuk dipecahkan atau diselesaikan, hukum harus ditegakkan, setiap pelanggaran hukum harus secara konsisten ditindak, dikenai sanksi. Kalau setiap pelanggaran hukum ditindak secara konsisten maka akan timbul rasa aman dan damai, karena ada jaminan kepastian hukum. Untuk itu diperlukan peradilan, yaitu pelaksanaan hukum dalam hal konkrit adanya tuntutan hak, fungsi mana dijalankan oleh suatu badan yang berdiri sendiri dan diadakan oleh negara serta bebas dari pengaruh apa atau siapapun dengan cara memberikan putusan yang bersifat mengikat dan bertujuan mencegah main hakim sendiri.

Masyarakat tak akan berfungsi tanpa hukum dan kaidah-kaidah lain didalamnya dan tak dapat maju kecuali melalui innovator yang giat dan berinisiatif. ${ }^{21}$ Demikianlah jelas bahwa secara nasional maupun internasional atau universal, independensi badan-badan peradilan dijamin. Satjipto Rahardjo berpendapat, untuk menyebarkan fora pendistribusi keadilan tidak semestinya terkonsentrasi hanya pada satu lembaga yang bernama pengadilan. Marc Galanter memberikan tamsil yang sangat bagus, yaitu hendaknya ada justice in many rooms. Gagasan Alternative Dispute Resolution sudah tersimpan lama sejak gelombang gerakan Access to Justice Movement, terutama gelombang ketiga yang menghendaki adanya jalur alternatif di luar pengadilan. Masalahnya karena masyarakat dapat mengalami keadilan atau ketidakadilan bukan saja melalui forum-forum yang disponsori oleh negara. ${ }^{22}$

\footnotetext{
${ }^{21}$ Soedjono Dirdjosisworo, Bertrand Russell, Cita-Cita Politik, Armico, Bandung, 1983, hlm. 52. Tertib dan teratur karena hukum berperan dalam masyarakat berkembang karena karya penemuan-penemuan para penemu dan pembaharu yang dengan tekun berusaha memperoleh sarana-sarana bagi kesejahteraan umat manusia.

${ }^{22}$ Eman Suparman, "Persepsi Tentang Keadilan Dan Budaya Hukum Dalam Penyelesaian Sengketa", Makalah Pada Seminar Nasional Tentang Pendayagunaan Sosiologi Hukum Dalam Masa Pembangunan Dan Restrukturisasi Global, Fakultas
}

Salah satu soal penting setelah penyempurnaan aturan kepailitan adalah pembentukan Pengadilan Niaga sebagai pengadilan khusus dalam lingkungan Peradilan Umum. Pengadilan Niaga yang pertama dibentuk adalah Pengadilan Niaga Jakarta Pusat. Selanjutnya berdasarkan Keppres Nomor 97 tahun 1999, Tanggal 18 Agustus 1998, didirikan Pengadilan Niaga di Makassar, Surabaya, Medan, dan Semarang. Pengadilan Niaga sangat diperlukan untuk menyelesaikan sengketa-sengketa niaga secara cepat; juga menyelesaikan aneka masalah kepailitan, seperti masalah pembuktian, verifikasi utang, actio pauliana, dan lain sebagainya. Di sinilah kadang terjadi persimpangan dengan kompetensi Pengadilan Negeri Jakarta Pusat dalam hal pemeriksaan perkara, teruama perkara-perkara yang bersifat perdata. Melalui Undang-Undang Kepailitan, kewenangan mutlak (kompetensi absolut). Pengadilan Umum untuk memeriksa permohonan pailit dialihkan ke Pengadilan Niaga.

\section{PEMBAHASAN \\ Mekanisme Permohonan Kepailitan Dan Akibat Hukum Pernyataan Kepailitan}

Secara normatif, makna utang di sini sangat luas. Utang yang terjadi bukan hanya karena perjanjian utang-piutang atau perjanjian kredit saja, tetapi juga kewajiban membayar sejumlah uang yang timbul dari perjanjian lainnya, antara lain seperti perjanjian sewa-menyewa, perjanjian jual beli, perjanjian pemborongan, perjanjian tukar-menukar, perjanjian sewa-beli, dan lainlain. Demikian juga halnya kewajiban membayar sejumlah uang yang timbul karena undang-undang adalah utang. Misalnya pajak yang belum dibayar kepada negara adalah utang. Selain itu, kewajiban membayar uang berdasarkan putusan pengadilan yang telah

Hukum UNDIP, Semarang, 12-13 Nopember 1996, hlm 3 . 
mempunyai kekuatan hukum tetap termasuk juga utang. ${ }^{23}$

Apabila debitur mengalami kesulitan keuangan, artinya tidak mampu membayar hutang-hutangnya, tentu saja para kreditur akan berusaha menempuh jalan untuk menyelamatkan piutangnya. Salah satu jalan yang ditempuh adalah kreditur mengajukan permohonan ke pengadilan agar si debitur dinyataan pailit. Permohonan itu disebut sebagai permohonan pernyataan kepailitan. Berhubung permohonan tersebut diajukan ke pengadilan, maka harus melewati prosedur yang benar.

Adapun cara-cara pengajuan permohonan pernyataan kepailitan menurut Pasal 6 Undang-Undang Kepailitan adalah sebagai berikut:

1. Permohonan pernyataan pailit diajukan kepada Ketua Pengadilan

2. Panitera mendaftarkan permohonan pernyataan pailit pada tanggal permohonan yang bersangkutan diajukan, dan kepada pemohon diberikan tanda terima tertulis yang ditandatangani oleh pejabat yang berwenang dengan tanggal yang sama dengan tanggal pendaftaran.

3. Panitera wajib menolak pendaftaran permohonan pernyataan pailit bagi institusi sebagaimana dalam Pasal 2 ayat 2, 3, 4,dan 5 jika dilakukan tidak sesuai dengan ketentuan dalam ayat-ayat tersebut.

4. Panitera menyampaikan permohonan pernyataan pailit kepada Ketua Pengadilan paling lambat 2 (dua) hari setelah tanggal permohonan didaftarkan.

5. Dalam jangka waktu paling lambat 3 (tiga) hari setelah tanggal permohonan pernyataan pailit didaftarkan, Pengadilan mempelajari permohonan dan menetapkan hari sidang.

6. Sidang pemeriksaan atas permohonan pernyataan pailit diselenggarakan dalam jangka waktu paling lambat 20 (dua puluh)

\footnotetext{
${ }^{23}$ Syamsudin Sinaga, Hukum Kepailitan Indonesia, Tianusa, Jakarta, 2012, hlm. 91.
}

hari setelah tanggal permohonan didaftarkan.

7. Atas permohonan Debitur dan berdasarkan alas an yang cukup, Pengadilan dapat menunda penyelenggaraan siding sebagaimana dimaksud pada ayat (5) sampai dengan paling lambat 25 (dua lima) hari setelah tanggal permohonan didaftarkan.

Mengenai permohonan pernyataan kepailitan, apabila yang mengajukan adalah suatu firma maka harus memuat nama dan tempat tinggal masing-masing persero yang secara tanggung renteng terikat untuk seluruh utang firma. Dan jika yang mengajukan permohonan pernyataan kepailitan adalah debitor yang masih terikat dalam pernikahan yang sah, maka menurut pasal 4 permohonan hanya dapat diajukan atas persetujuan suami atau istrinya. Dan permohonan pernyataan pailit harus dikabulkan apabila terdapat fakta atau keadaan yang terbukti secara sederhana (yakni pembuktian secara sumir) bahwa persyaratan untuk pailit sebagaimana dimaksud dalam pasal 2 telah terpenuhi. Demikian juga bila permohonan diajukan oleh kreditur, pembuktian hak kreditur untuk menagih juga dilakukan secara sederhana juga.

Putusan atas permohonan pernyataan pailit harus diucapkan paling lambat 60 (enam puluh) setelah tanggal permohonan pernyataan pailit didaftarkan. Putusan tersebut harus diucapkan dalam siding terbuka untuk umum sebagaimana ketentuan Pasal 8 ayat (7) dan dapat dijalankan terlebih dahulu, meskipun terhadap putusan tersebut diajukan suatu upaya hukum. Pengadilan wajib menyampaikan salinan putusan pengadilan melalui juru sita kepada debitur, pihak yang mengajukan permohonan pernyataan pailit dan kurator serta hakim pengawas paling lambat 3 (tiga) hari setelah tanggal putusan atas permohonan pernyataan pailit diucapkan.

Untuk melindungi kepentingan kreditur yang selama ini sering diakali oleh debitur nakal, maka di dalam Pasal 10 UUK ditetapkan bahwa selama putusan atas 
permohonan pernyataan pailit belum belum diucapkan, setiap kreditor, kejaksaan, Bank Indonesia, Badan Pengawas Pasar Modal, atau Menteri Keuangan dapat mengajukan permohonan kepada pengadilan untuk :

1. Meletakkan sita jaminan terhadap sebagian atau seluruh kekayaan debitur, atau;

2. Menunjuk kurator sementara untuk mengawasi : Pengelolaan usaha debitur, dan; Pembayaran kepada Kreditur, pengalihan, atau pengagunan kekayaan Debitur yang dalam kepailitan merupakan wewenang Kurator.

Namun, apabila pengadilan sudah memutuskan untuk mengambulkan permohonan pernyataan pailit, keputusan itu akan mengakhiri semua kepengawasan Kurator semestara dan debitur menjadi pailit, kehilangan kepemilikan atas segala asetnya. Selama putusan atas permohonan pernyataan pailit belum ditetapkan, kreditur atau kejaksanaan dapat mengajukan permohonan kepada pengadilan untuk :

1. Meletakkan sita jaminan terhadap sebagian atau seluruh kekayaan debitur;

2. Menunjuk kurator sementara untuk : Mengawasi pengelolaan usaha debitur. Mengawasi pembayaran kepada kreditur, pengadilan atau penggunaan kekayaan debitur yang dalam rangka kepailitan memrlukan persetujuan kurator.

Dengan pernyataan pailit, debitur pailit demi hukum kehilangan hak untuk menguasai dan mengurus kekayaannya yang dimaksudkan dalam kepailitan, terhitung sejak tanggal kepailitan itu. Akibat hukum lain yang juga amat penting dari pernyataan pailit adalah bahwa untuk kepentingan harta pailit dapat dimintakan pembatalan atas segala perbuatan hukum debitur yang telah dinyatakan pailit yang merugikan kepentingan kreditur, yang dilakukan sebelum pernyataan pailit ditetapkan. Akibat hukum lainnya adalah adanya hak retensi yang diatur dalam Pasal 59 yaitu hak kreditur untuk menahan barang-barang kepunyaan debitur hingga dibayarnya suatu utang tidak kehilangan hak untuk menahan barang dengan diucapkannya pernyataan pailit. Apabila curator bermaksud untuk menebus barang-barang tersebut, maka kurator wajib melunasi utang debitur pailit tersebut terlebih dahulu.

Suatu Putusan Pernyataan pailit mengubah status hukum debitor menjadi tidak cakap untuk melakukan perbuatan hukum, menguasai, dan mengurus harta kekayaannya sejak putusan pernyataan pailit diucapkan. Akibat lain dari putusan pernyataan pailit antara lain:

1. Debitor demi hukum kehilangan haknya untuk menguasai dan mengurus kekayaannya yang termasuk dalam harta pailit.

2. Kepailitan hanya mengenai harta pailit dan tidak mengenai diri pribadi debitor pailit.

3. Harta pailit diurus dan dikuasai kurator untuk kepentingan semua para kreditor dan debitor dengan pengawasan dari Hakim pengawas.

4. Tuntutan dan gugatan mengenai hak dan kewajiban harta pailit harus diajukan oleh atau terhadap kurator.

5. Segala perbuatan debitor yang dilakukan sebelum dinyatakan pailit, apabila dapat dibuktikan bahwa perbuatan tersebut secara sadar dilakukan debitor untuk merugikan kreditor, maka dapat dibatalkan oleh kurator atau kreditor. Istilah ini disebut dengan actio pauliana.

6. Hibah yang dilakukan Debitor dapat dimintakan pembatalan kepada Pengadilan, apabila Kurator dapat membuktikan bahwa pada saat hibah tersebut dilakukan Debitor mengetahui atau patut mengetahui bahwa tindakan tersebut akan mengakibatkan kerugian bagi Kreditor.

7. Perikatan selama kepailitan yang dilakukan debitor, apabila perikatan tersebut menguntungkan bisa diteruskan. Namun apabila perikatan itu merugikan, maka kerugian sepenuhnya ditanggung oleh debitor secara pribadi,atau perikatan itu dapat dimintakan pembatalan.

8. Hak eksekusi kreditor dan pihak ketiga untuk menuntut yang berada dalam penguasaan debitor pailit atau kurator, 
ditangguhkan dalam jangka waktu paling lama 90 (sembilan puluh) hari.

9. Hak untuk menahan benda milik debitor (hak retensi) tidak hilang.

10. Kepailitan suami atau istri yang kawin dalam suatu persatuan harta, diperlakukan sebagai kepailitan persatuan harta tersebut.

Harta pailit ini meliputi seluruh kekayaan Debitor pada saat putusan pernyataan pailit diucapkan serta segala sesuatu yang diperoleh selama kepailitan. Harta tersebut pengurusannya beralih ke tangan kurator. Namun, tidak semua harta kekayaan debitor dalam disita dalam kepailitan. Pasal 22 UUK menyebutkan, ada tiga jenis kekayaan debitor yang tidak termasuk ke dalam harta pailit, yaitu :

1. Benda, termasuk hewan yang benar-benar dibutuhkan oleh Debitor sehubungan dengan pekerjaannya, perlengkapannya, alat-alat medis yang dipergunakan untuk kesehatan, tempat tidur dan perlengkapannya yang dipergunakan oleh Debitor dan keluarganya, dan bahan makanan untuk 30 (tiga puluh) hari bagi Debitor dan keluarganya, yang terdapat di tempat itu;

2. Segala sesuatu yang diperoleh Debitor dari pekerjaannya sendiri sebagai penggajian dari suatu jabatan atau jasa, sebagai upah, pensiun, uang tunggu atau uang tunjangan, sejauh yang ditentukan oleh Hakim Pengawas; atau

3. Uang yang diberikan kepada Debitor untuk memenuhi suatu kewajiban memberi nafkah menurut undang-undang.

Sebagaimana telah disebutkan di atas tadi bahwa dengan dikeluarkannya putusan pernyataan pailit tersebut, debitor terhitung sejak pukul 00.00 waktu setempat demi hukum kehilangan haknya untuk menguasai dan mengurus kekayaannya yang termasuk dalam harta pailit. Namun, perlu diketahui juga bahwasannya putusan pernyataan pailit tidak mengakibatkan debitor kehilangan kecakapannya untuk melakukan perbuatan hukum (volkomen handelingsbevoegd) pada umumnya, tetapi hanya kehilangan kewenangannya untuk mengurus dan mengalihkan harta kekayaannya saja.

Kewenangan debitor itu selanjutnya diambil alih oleh kurator yang diangkat oleh pengadilan, dengan diawasi oleh seorang Hakim Pengawas. Pengangkatan tersebut harus ditetapkan dalam putusan pernyataan pailit. Pelaksanaan pengurusan harta pailit oleh kurator bersifat seketika, dan berlaku saat itu pula terhitung sejak tanggal putusan ditetapkan meskipun terhadap putusan itu kemudian diajukan kasasi atau peninjauan kembali. Sesudah pernyataan pailit tersebut maka segala perikatan yang dibuat debitor dengan pihak ketiga tidak dapat dibayar dari harta pailit, kecuali bila perikatan-perikatan tersebut mendatangkan kuntungan bagi harta pailit atau dapat menambah harta pailit.

Oleh karena itu, gugatan-gugatan yang diajukan dengan tujuan untuk memperoleh pemenuhan perikatan dari harta pailit, selama dalam kepailitan, yang secara langsung diajukan kepada debitor pailit, hanya dapat diajukan dalam bentuk laporan untuk pencocokan atau rapat verifikasi. Segala tuntutan mengenai hak atau kewajiban yang menyangkut harta pailit harus diajukan oleh atau terhadap kurator. Begitu pula mengenai segala eksekusi pengadilan terhadap harta pailit. Eksekusi pengadilan terhadap setiap bagian dari kekayaan debitor yang telah dimulai sebelum kepailitan harus dihentikan, kecuali eksekusi itu sudah sedemikian jauh hingga hari pelelangan sudah ditentukan, dengan izin hakim pengawas kurator dapat meneruskan pelelangan tersebut.

Lalu, tentang perkara yang sedang berjalan atau suatu tuntutan hukum yang sedang berjalan dimana debitor menjadi Penggugat dimana ia sudah tidak cakap lagi, maka di sini pihak tergugat dapat memohon agar perkara tersebut ditanguhkan terlebih dahulu untuk memanggil kurator guna mengambil alih perkara. Namun, bila kurator tidak mengindahkan panggilan tersebut, maka tergugat berhak memohon agar perkara itu digugurkan saja. Pada dasarnya dengan 
diucapkannya putusan pailit terhadap debitor, semua tuntutan hukum yang diajukan terhadapnya yang bertujuan untuk memperoleh pemenuhan kewajiban dari harta pailit dan perkara yang sedang berjalan menjadi gugur demi hukum. Dalam hal perkara tersebut dilanjutkan oleh kurator, maka kurator dapat mengajukan pembatalan atas segala perbuatan yang dilakukan oleh debitor sebelum debitor dinyatakan pailit.

Terhadap perjanjian timbal balik yang dilakukan oleh debitor dimana debitor sendiri belum memenuhi perjanjian atau baru dipenuhi sebagian, maka pihak pihak yang mengadakan perjanjian dengan debitor dapat meminta kepada kurator untuk memberikan kepastian tentang kelanjutan pelaksanaan perjanjian tersebut dalam jangka waktu yang disepakati oleh kurator dan pihak yang bersangkutan. Bila kesepakatan tentang jangka waktu itu tidak tercapai, maka Hakim Pengawaslah yang menetapkan jangka waktu yang dimaksud. Kurator yang sangup melanjutkan perjanjian itu harus memberikan kepastian dengan memberi jaminan untuk melaksanakan perjanjian tersebut. Bila yang terjadi sebaliknya, dimana kurator tidak mau melanjutkan perjanjian itu, maka perjanjian tersebut berakhir, untuk menuntut haknya, pihak yang bersangkutan dapat menjadi kreditor konkuren.

Mengenai perjanjian sewa menyewa yang dilakukan oleh debitor pailit, dimana debitor menjadi pihak yang menyewa maupun pihak yang menyewakan, maka perjanjian sewa menyewa itu dapat dihentikan tentu dengan syarat harus ada pemberitahuan terlebih dahulu menurut adat kebiasaan setempat. Bila ternyata uang sewa telah dibayar di muka, maka perjanjian sewa ini tidak dapat dihentikan lebih awal sebelum berakhirnya jangka watu yang telah dibayar dan sejak putusan pailit itu diucapkan maka uang sewa masuk ke dalam harta pailit.

Hal lain yang patut menjadi perhatian ialah tentang nasib pekerjan yang bekerja untuk debitor. Kita ketahui dengan putusan pailit itu dapat dipastikan akan terjadi
Pemutusan Hubungan Kerja (PHK) secara besar-besaran. Di Indonesia sendiri masalah ketenagakerjaan diatur dalam UndangUndang Nomor 13 Tahun 2003 Tentang Ketenagakerjaan. Undang-Undang memberikan jaminan hak hak dasar pekerja/buruh dan menjamin kesamaan kesempatan serta perlakuan tanpa diskriminasi atas dasar apapun untuk mewujudkan kesejahteraan pekerja/buruh dan keluarganya dengan tetap memperhatikan perkembangan kemajuan dunia usaha karena dalam pelaksanaan pembangunan nasional, tenaga kerja mempunyai peranan dan kedudukan yang sangat penting sebagai pelaku dan tujuan pembangunan.

Dalam

Undang-Undang Ketenagakerjaan sendiri juga diatur mengenai masalah Pemutusan Hubungan Kerja yang terjadi karena perusahaan mengalami pailit. Dalam Pasal 165 Undang-Undang Ketenagakerjaan menyatakan bahwa Pengusaha dapat melakukan pemutusan hubungan kerja terhadap pekerja/ buruh karena perusahaan pailit, dengan ketentuan pekerja/ buruh berhak atas uang pesangon sebesar 1 (satu) kali ketentuan Pasal 156 ayat (2), uang penghargaan masa kerja sebesar 1 (satu) kali ketentuan Pasal 156 ayat (3) dan uang penggantian hak sesuai ketentuan Pasal 156 ayat (4).

Jika debitor pailit itu seorang suami atau istri, Pasal 62 Undang-Undang Kepailian menyatakan bahwa dalam hal suami atau istri dinyatakan pailit maka istri atau suaminya berhak mengambil kembali semua benda bergerak dan tidak bergerak yang merupakan harta bawaan dari istri atau suami dan harta yang diperoleh masing-masing sebagai hadiah atau warisan. Jika benda milik istri atau suami telah dijual oleh suami atau istri dan harganya belum dibayar atau uang hasil penjualan belum tercampur dalam harta pailit maka istri atau suami berhak mengambil kembali uang hasil penjualan tersebut. 


\section{Kedudukan Hukum Debitur Setelah Berakhirnya Pemberesan Harta Pailit}

Suatu pemberesan harta pailit baru dapat dilakukansetelah debitur dalam keadaan insolvensi. Suatu kepailitan dapat berakhir karena :

1. Kepailitan dicabut karena harta pailit tidak cukup untuk membayar biaya kepailitan (Pasal 18 UUK dan PKPU).

2. Perdamaian yang telah ditawarkan oleh debitur atau kreditur telah diterima dan disahkan oleh hakim pengawas.

3. Apabila harta pailit telah dijual seluruhnya dan hasil penjualan tersebut telah dibagi seluruhnya kepada kreditur.

4. Apabila putusan pailit dibatalkan di tingkat kasasi atau peninjauan kembali.

Setelah dilakukan pemberesan terhadap harta pailit, maka kemungkinan akan terjadi suatu kondisi bahwa harta pailit tersebut mencukupi untuk membayar utang-utang debitur kepada para krediturnya atau sebaliknya harta pailit tidak dapat mencukupi pelunasan terhadap utang-utang debitur kepada para kreditur. Bila harta pailit mampu mencukupi pembayaran utang-utang debitur pailit kepada para krediturnya, maka langkah selanjutnya adalah rehabilitasi. Rehabilitasi adalah pemulihan nama baik debitur yang semula dinyatakan pailit, melalui putusan pengadilan yang menerangkan bahwa debitur telah memenuhi kewajibannya.

Permohonan rehabilitasi harus diumumkan paling sedikit dalam 2 (dua) surat kabar harian yang ditunjuk oleh Pengadilan Niaga. Dalam jangka waktu 60 hari (enam puluh hari) setelah permohonan rehabilitasi diumumkan paling sedikit dalam 2 (dua) surat kabar harian, setiap kreditur yang diakui dapat mengajukan keberatan terhadap permohonan tersebut, dengan mengajukan surat keberatan, disertai alasan di kepaniteraan pengadilan dan panitera harus memberikan tanda terima.

Keberatan tersebut hanya dapat diajukan apabila persyaratan surat permohonan tersebut dilampirkan bukti yang menyatakan bahwa semua kreditur yang diakui sudah memperoleh pembayaran secara memuaskan tidak terpenuhi. Yang dimaksud dengan pembayaran yang memuaskan adalah bahwa kredituryang diakui tidak akan mengajukan tagihan lagi terhadap debitur, sekalipun mereka mungkin tidak menerima pembayaran atas seluruh tagihannya.

Setelah berakhirnya jangka 60 (enam puluh) hari tersebut, terlepas apakah kreditur mengajukan atau tidak mengajukan keberatan, pengadilan harus memutuskan apakah mengabulkan atau menolak permohonan tersebut.Putusan pengadilan tersebut adalah putusan final dan binding, dalam arti tidak terbuka upaya hukum apapun termasuk banding atau kasasi. Putusan yang mengabulkan rehabulitasi tersebut wajib diucapkan dalam sidang yang terbuka untuk umum dan harus didaftar dalam daftar umum.

Tujuan utama rehabilitasi adalah untuk mengembalikan debitur pailit ke keadaan semula seperti sebelum jatuh pailit. Dengan berakhirnya kepailitan, dengan sendirinya debitur pailit kembali ke keadaan semula tanpa perlu adanya permohonan rehabilitasi. Dengan adanya rehabilitasi secara resmi tersebut, debitur pailit akan memperoleh kepercayaan umum kembali dan dapat melanjutkan usahanya tanpa beban. Dari UUK dan PKPU bahwa kepailitan sebagai sita umum dengan putusan pernyataan Pengadilan Niaga hanya mengenai harta kekayaan debitur pailit, bukan terhadap orang atau pribadinya sebagai subyek hukum. Dengan tidak membedakan antara debitur yang jujur atau tidak jujur, dimungkinkan dalam keadaan debitur tidak memenuhi kewajiban para kreditur dan debitur.

Permohonan rehabilitasi diajukan kepada Pengadilan Niaga yang semula memeriksa kepailitan yang bersangkutan. Akan tetapi, tidak terhadap semua kepailitan dapat dimintakan rehabilitasi. Hanya terhadap putusan kepailitan di bawah ini yang dapat diajukan rehabilitasi, yaitu sebagai berikut:

1. Apabila kepailitan diakhiri dengan suatu perdamaian.

2. Apabila diakhiri setelah utangnya dibayar penuh. 
3. Apabila kepailitan tersebut dijatuhkan atas harta benda debitur.

Dengan demikian, jika kreditur tidak dapat membayar lunas atau tidak terjadi perdamaian, terhadap hal tersebut tidak berlaku rehabilitasi. Namun, kepailitan dapat berakhir dan debitur pailit memperoleh kembali wewenangnya untuk melakukan tindakan pengurusan dan pemilikan (daden van beheer er daden van eigendom). Oleh karena itu, jika debitur berusaha lagi setelah pailit dihapus, kreditur tetap dapat meminta sisa utangnya dibayar penuh, tanpa perlu mengajukan gugatan baru, tetapi hanya minta dijalankan putusan pailit yang sudah ada sampai semua utangnya yang telah diverifikasi dibayar lunas.53 Sebab, suatu pengakuan utang dalam kepailitan mempunyai kekuatan hukum yang sama dengan keputusan pengadilan. Jadi, hanya tinggal memohon pengeksekusiannya.

\section{Upaya Hukum Dalam Kepailitan Dalam Menciptakan Iklim Usaha Yang Baik}

Tujuan utama dalam suatu proses di muka Pengadilan adalah untuk memperoleh putusan Hakim yang berkekuatan hukum tetap. Akan tetapi, setiap putusan yang dijatuhkan oleh Hakim belum tentu dapat menjamin kebenaran secara yuridis, karena putusan itu tidak lepas dari kekeliruan dan kekilafan, bahkan tidak mustahil bersifat memihak. Agar kekeliruan dan kekilafan itu dapat diperbaiki, maka demi tegaknya kebenaran dan keadilan, terhadap putusan Hakim itu dimungkinkan untuk diperiksa ulang. Cara yang tepat untuk dapat mewujudkan kebenaran dan keadilan itu adalah dengan melaksanakan upaya hukum.

Demikian pula terhadap putusan dari Pengadilan Niaga dalam perkara kepailitan. Namun, perbedaan dari Pengadilan Niaga ialah hanya tersedia upaya hukum kasasi ke Mahkamah Agung. Pengadilan Niaga disebut sebagai pengadilan tingkat pertama dan tidak ada tingkat kedua atau sering disebut sebagai tingkat banding. Terhadap putusan-putusan yang telah memperoleh kekuatan hukum tetap, tersedia upaya hukum luar biasa yaitu peninjauan kembali.

1. Kasasi

Sebagaimana disebutkan dalam Undang-Undang Nomor 4 Tahun 2004 tentang Mahkamah Agung, bahwa salah satu tugas dan wewenang Mahkamah Agung adalah memeriksa dan memutus permohonan kasasi. Pasal 30 ayat (1) Undang-Undang Mahkamah Agung menyebutkan bahwa Mahkamah Agung dalam tingkat kasasi membatalkan putusan atau penetapan pengadilan-pengadilan dari semua lingkungan peradilan karena:

a. tidak berwenang atau melampaui batas wewenang;

b. salah menerapkan atau melanggar hukum yang berlaku;

c. lalai memenuhi syarat-syarat yang diwajibkan oleh peraturan perundangundangan yang mengancam kelalaian itu dengan batalnya putusan yang bersangkutan.

Prosedur Permohonan Kasasi atas Putusan Pailit. Upaya hukum kasasi dalam kepailitan diatur dalam Pasal 11 sampai dengan Pasal 13 Undang-Undang Kepailitan, prosesnya dapat dijelaskan sebagai berikut:

a. Pendaftaran Kasasi

b. Penyampaian Memori Kasasi

c. Pengajuan Kontra Memori Kasasi

d. Pegiriman Berkas ke Mahkamah Agung

e. Sidang Pemeriksaan

f. Putusan Kasasi

\section{Peninjauan Kembali}

Kewenangan lain yang diberikan Undang-Undang kepada Mahkamah Agung ialah memeriksa dan memutus permohonan peninjauan kembali yang telah mempunyai kekuatan hukum tetap. Peninjauan Kembali merupakan upaya hukum luar biasa, namun sebenarnya lembaga ini bertentangan dengan asas kepastian hukum. Prinsip asas kepastian hukum menentukan bahwa putusan hakim yang sudah berkekuatan hukum tetap, tidak bisa diubah lagi. Asas kepastian hukum ini disebut nebis in idem, artinya tidak boleh 
terjadi dua kali putusan terhadap satu kasus yang sama antara dua pihak dalam perkara yang sama.

Undang-Undang memberi kesempatan untuk mengajukan peninjauan kembali dengan segala persyaratan yang ketat. Persyaratan yang ketat tersebut dimaksudkan untuk menerapkan asas keadilan terhadap pemberlakuan asas kepastian hukum, karena itu peninjauan kembali berorientasi pada tuntutan keadilan. Fungsi Mahkamah Agung dalam Peninjauan Kembali adalah mengadakan koreksi terakhir terhadap putusan pengadilan yang mengandung ketidakadilan yang disebabkan kesalahan dan kekhilafan hakim.

Peninjauan Kembali dalam Kepailitan. Rumusan Pasal 14 Undang-Undang Nomor 37 Tahun 2004 memberikan hak untuk mengajukan perninjauan kembali atas putusan pailit yang telah berkekuatan hukum tetap. Walau demikian permohonan peninjauan kembali hanya dapat dilakukan pada dua macam alasan saja, yang masing-masing secara khusus telah dibatasi jangka waktu tertentu. Pasal 295 ayat (2) Undang-Undang Kepailitan menentukan bahwa peninjauan kembali dapat diajukan dengan alasan sebagai berikut:

a. Setelah perkara diputus ditemukan bukti baru yang bersifat menentukan yang pada waktu perkara diperiksa di Pengadilan sudah ada, tetapi belum ditemukan. Bukti baru tersebut apabila diketahui pada tahap persidangan sebelumnya akan menghasilkan putusan yang berbeda. Permohonan peninjauan kembali dengan alasan ini diajukan dilakukan dalam jangka waktu paling lambat 180 (seratus delapan puluh) hari setelah tanggal putusan yang dimohonkan peninjauan kembali memperoleh kekuatan hukum tetap.

b. Terdapat kekeliruan yang nyata pada putusan hakim sebelumnya atau hakim telah melakukan kesalahan berat dalam penerapan hukum. Permohonan peninjauan kembali atas dasar alasan ini, dilakukan dalam jangka waktu paling lambat 30 (tiga puluh) hari setelah tanggal putusan yang dimohonkan peninjauan kembali memperoleh kekuatan hukum tetap.

Prosedur permohonan peninjauan kembali diatur tersendiri pada BAB IV, Pasal 295 sampai dengan 298 Undang-Undang Kepailitan. Permohonan peninjauan kembali disampaikan kepada Panitera Pengadilan. Panitera Pengadilan mendaftar permohonan peninjauan kembali pada tanggal permohonan diajukan, dan kepada pemohon diberikan tanda terima tertulis yang ditandatangani Panitera Pengadilan dengan tanggal yang sama dengan tanggal permohonan didaftarkan. Panitera Pengadilan menyampaikan permohonan peninjauan kembali kepada Panitera Mahkamah Agung dalam jangka waktu 2 (dua) hari setelah tanggal permohonan didaftarkan.

Pemohon peninjauan kembali wajib menyampaikan kepada Panitera Pengadilan bukti pendukung yang menjadi dasar pengajuan permohonan peninjauan kembali dan untuk termohon salinan permohonan peninjauan kembali berikut salinan bukti pendukung yang bersangkutan, pada tanggal permohonan didaftarkan. Panitera Pengadilan menyampaikan salinan permohonan peninjauan kembali berikut salinan bukti pendukung kepada termohon dalam jangka waktu paling lambat 2 (dua) hari setelah tanggal permohonan didaftarkan.

Pihak termohon dapat mengajukan jawaban terhadap permohonan peninjauan kembali yang diajukan, dalam jangka waktu 10 (sepuluh) hari setelah tanggal permohonan peninjauan kembali didaftarkan. Panitera Pengadilan wajib menyampaikan jawaban kepada Panitera Mahkamah Agung, dalam jangka waktu paling lambat 12 (dua belas) hari setelah tanggal permohonan didaftarkan.

Mahkamah Agung segera memeriksa dan memberikan putusan atas permohonan peninjauan kembali dalam jangka waktu paling lambat 30 (tiga puluh) hari setelah tanggal permohonan diterima Panitera Mahkamah Agung. Putusan atas permohonan peninjauan kembali harus diucapkan dalam 
sidang terbuka untuk umum. Dalam jangka waktu paling lambat 32 (tiga puluh dua) hari setelah tanggal permohonan diterima Panitera Mahkamah Agung, Mahkamah Agung wajib menyampaikan kepada para pihak salinan putusan peninjauan kembali yang memuat secara lengkap pertimbangan hukum yang mendasari putusan tersebut.

\section{Peran Advokat Dalam Menerapkan Undang-Undang Kepailitan Guna Menjaga Iklim Usaha Yang Baik}

Menjadi advokat di bidang kepailitan bukan pekerjaan mudah. Setidaknya ini pandangan dari advokat yang menangani kasus-kasus kepailitan, ada banyak hal yang perlu dipahami dan dilakukan untuk menjadi advokat kepailitan. Menjadi pengacara kepailitan adalah memahami UU No. 37 Tahun 2004 tentang Kepailitan dan Penundaan Kewajiban Pembayaran Utang (UU Kepailitan). Memahami UU ini harus sampai ke akar-akarnya, yakni apa filosofi UU ini dilahirkan. Pertama sekali memang seorang advokat harus memahami dulu filosofi hukum kepailitan atau arti undangundang kepailitan itu dibuat apa.

Banyak orang yang sering salah sangka menafsirkan tujuan utama UU ini, menilai tujuan utamanya adalah untuk memaksa debitur atau kreditur; atau untuk kepentingan debitur atau kreditur. Padahal itu hanya tujuan antara, tujuan akhirnya sebenarnya yang paling tepat dari Undang-Undang Kepailitan adalah, dia merupakan undang-undang yang memastikan bahwa seluruh pelaku usaha melakukan aktivitas usahanya secara baik dan benar. Dia tidak bisa misalnya melakukan ekspansi dengan cara tidak terukur. Pelaku usaha harus memahami tren dalam pembangunan produk. Selain itu, pengusaha harus juga memahami hal-hal yang berhubungan dengan tata cara pengelolaan yang baik dan benar. Dia juga harus punya rasa malu apabila tidak memegang komitmen. Ini lah yang harus disampaikan advokat kepada kliennya.
Selain Undang-Undang Kepailitan, peraturan perundang-undangan terkait, sederet undang-undang yang perlu dipahami oleh para advokat kepailitan adalah :

1. Undang-Undang No. 40 Tahun 2007 tentang Perseroan Terbatas

2. Undang-Undang Perkoperasian

3. Undang-Undang No. 28 Tahun 2004 tentang Yayasan

4. Undang-Undang No. 13 Tahun 2003 tentang Ketenagakerjaaan

5. Undang-Undang lain yang berkaitan dengan penjaminan

Bahwa peraturan perundang-undangan yang berkaitan dengan kepailitan sangat kompleks, sehingga pemahaman yang utuh sangat dibutuhkan. Dengan pemahaman itu, akan membangun sikap para advokat kepailitan dan juga tentunya memahami hukum acara. Selain itu para advokat tidak melupakan dasar dari kepailitan, yakni hukum perdata beserta hukum acara perdata. Dia harus sangat-sangat paham. Dari pemahaman itu, maka dia akan masuk ke dunia praktik. setelah memahami seluruh aturan itu secara utuh, maka selanjutnya perlu bertindak secara benar berdasarkan aturan-aturan tersebut. Dalam konteks ini, bisa memberikan advise yang benar buat kliennya, bisa memberikan satu pelajaran buat kliennya untuk misalnya memahami hal-hal mana yang sepatutnya dilakukan.

Seorang advokat yang baik adalah advokat yang memastikan bahwa akan berarti buat kliennya. Maksudnya, berarti dalam meng-advise kliennya. Selain mengajarkan klien atas hal-hal yang patut dilakukan, advokat juga perlu mengingatkan bahwa dalam proses berperkara khususnya dalam perkara kepailitan bila kliennya tak mau dicurangi, maka jangan pula melakukan hal mencurangi orang lain. Bertindak secara benar akan menciptakan hal yang positif, yakni advokat akan terus belajar ketika menangani sebuah kasus. Jika advokat itu melakukan sesuatu dengan benar, dia memaksa otaknya bekerja, ilmunya berguna. Karena advokat yang baik adalah advokat 
yang juga memastikan bahwa dia mempunyai ilmu yang cukup dan juga moral yang baik. ${ }^{24}$

Advokat sebagai profesi yang bebas, mandiri, dan bertanggung jawab dalam menegakkan hukum, perlu dijamin dan dilindungi oleh undang-undang demi terselenggaranya upaya penegakan supremasi hukum. Lahirnya Undang-Undang Nomor 18 Tahun 2003 tentang Advokat menjadi landasan hukum penting bagi profesi Advokat sebagai salah satu pilar penegak hukum. Hal ini ditegaskan dalam Pasal 5 ayat (1) UndangUndang Nomor 18 Tahun 2003 tersebut, yang menyatakan bahwa Advokat berstatus penegak hukum, bebas dan mandiri yang dijamin oleh hukum dan peraturan perundangundangan. Dalam Penjelasan Pasal 5 ayat (1) Undang-Undang Nomor 18 Tahun 2003 lebih ditegaskan lagi, bahwa yang dimaksud dengan "Advokat berstatus sebagai penegak hukum" adalah Advokat sebagai salah satu perangkat dalam proses peradilan yang mempunyai kedudukan setara dengan penegak hukum lainnya dalam menegakan hukum dan keadilan.

Dalam menjalankan tugas membela kepentingan klien, sorang advokat memiliki kebebasan. Kebebasan tersebut dimaksudkan agar advokat dapat bertindak luwes dalam menjalankan tugas. Kebebasan itu sendiri bukan berarti advokat bebas bertindak semuanya atau sebebas-bebasnya, tetapi kebebasan yang terbatas. Kebebasan dalam mengurus perkara kliennya di batasi oleh kode petik profesi dan peraturan perundangundangan yang berlaku. Perbuatan advokat dibatasi antara lain oleh KUHAP, KUHP, KIR, Undang-Undang Advokat. ${ }^{25}$

\footnotetext{
24“"Empat Kiat Jadi Advokat Kepailitan Yang Handal, Jika Tak Mau Dicurangi, Jangan Curangi Orang Lain", http://www.hukumonline. com/berital baca/lt5582549f59b6el empat- kiat- jadi- advokatkepailitan- yang- handal, diakses tanggal 10 September 2017.

${ }^{25}$ Gatot Supramono, Bagaimana Mendampingi Seseorang di Pengadilan: Dalam Perkara Pidana dan Perkara Perdata, Djambatan, Jakarta, 2008, hlm. 14.
}

Profesi advokat tidak bisa dilepaskan dari Kode Etik (Code of conduct) yang memiliki nilai dan moral di dalamnya. Di Indonesia, satu-satunya organisasi Advokat yang diakui adalah Perhimpunan Advokat Indonesia (PERADI) yang didirikan berdasarkan perintah dan sesuai dengan Undang-Undang Nomor 18 Tahun 2003 Tentang advokat serta mendapat kekuatan konstitusional oleh mahkamah Konstituso dalam Putusan Perkara Nomor 014/PUUIV/2006 dengan memberikan kedudukan "PERADI sebagai organ Negara. ${ }^{26}$

Advokat dalam menjalankan tugas dilarang membeda-bedakan karena jenis kelamin, agama, politik, keturunan, ras, atau latar belakang sosial dan budaya. Advokat tidak dapat diidentikan dengan kliennya dalam membela perkara kliennya. Seperti dijelaskan dalam Pasal 18 dan Pasal 20 Undang-Undang No. 18 Tahun 2003 tentang Advokat. ${ }^{27}$

Tiap profesi termasuk Advokat menggunakan sistem etika, terutama untuk menyediakan struktur yang mampu menciptakan disiplin tata kerja, dan menyediakan garis batas tata nilai yang bisa dijadikan acuan para profesional untuk menyelesaikan dilemma etika yang dihadapi saat menjalankan fungsi pengemban profesinya sehari-hari. Sistem etika tersebut bisa juga menjadi parameter bagi berbagai problematika profesi pada umumnya, seperti menjaga kerahasiaan dalam hubungan klien profesional, konflik kepentingan yang ada, dan isu-isu yang berkaitan dengan tanggung jawab sosial profesi.

Dalam menjalankan tugas membela kepentingan klien, seorang advokat memiliki peran dalam proses kepailitan, dalam kaitannya dengan perseroan terbatas (PT), diantaranya adalah kebebasan. Kebebasan

\footnotetext{
${ }^{26}$ Indonesia, Undang-Undang Advokat, UndangUndang No. 18 Tahun 2003 tentang Advokat Lembaran Negara Republik Indonesia Tahun 2003 Nomor 49, Tambahan Lembaran Negara Republik Indonesia Nomor 4288.

${ }^{27}$ Ibid., Pasal 18 dan Pasal 20.
} 
tersebut dimaksudkan agar advokat dapat bertindak luwes dalam menjalankan tugas. Kebebasan itu sendiri bukan berarti advokat bebas bisa bertindak semuanya atau sebebasbebasnya, tetapi kebebasan yang terbatas. Kebebasan dalam mengurus perkara kliennya dibatasi oleh kode etik profesi dan peraturan perundang-undangan yang berlaku (Pasal 15 Undang-Undang Advokat). Perbuatan advokat dibatasi antara lain oleh KUHAP, KUHP, HIR, Undang-Undang Advokat.

Dengan kebebasan yang dimilikinya, advokat bebas dalam menyampaikan pendapat atau pernyataan dalam membela perkara di ruang sidang pengadilan. Pernyataan atau pendapat itu disampaikan dengan bernada keras, menyindir, membuat kuping panas, cenderung memperolok pihak lain, dan masih banyak yang tidak enak lainnya. Hal ini tidak akan menjadi masalah sepanjang dilakukan dengan itikad baik dan semata-mata hanya untuk membela kepentingan klien di persidangan.

Konsekuensi dari adanya kebebasan tersebut, advokat tidak dapat dituntut secara hukum, baik perdata maupun pidana. Dasar hukumnya adalah Pasal 16 Undang-Undang Advokat. Pasal ini merupakan jaminan hukum bagi para advokat dalam melaksanakan kebebasannya. Kebebasan advokat juga termasuk tidak dapat dipengaruhi oleh pihak lain. Hubungan advokat dengan kliennya harus dapat dipertahankan sampai tugas memberi jasa hukum benar-benar telah selesai. Pengaruh pihak luar terhadap pekerjaan advokat akan terganggu dan dapat berakibat merugikan kepentingan klien. Jadi siapapun juga tidak boleh mengintervensi kebebasan advokat. Dengan menghargai kebebasan advokat diharapkan akan berpengaruh terhadap penegakan hukum dan keadilan masyarakat.

Undang-undang advokat Pasal 1 huruf a merumuskan advokat sebagai orang yang berprofesi memberi jasa hukum, baik di dalam maupun di luar pengadilan yang memenuhi persyaratan berdasarkan undangundang ini. Dan pada Pasal 1 huruf $b$ dijelaskan secara definitif yang dikategorikan sebagai jasa hukum adalah konsultasi hukum, bantuan hukum, menjalankan kuasa, mewakili, mendampingi, membela dan melakukan tindakan hukum lain untuk kepentingan klien. Dalam terjemahan tekstual pada rumusan pasal di atas, advokat diterjemahkan secara umum sebagai suatu profesi belaka, namun tidak menyinggung posisi advokat dalam hubungannya dengan negara yang memiliki karakter khusus dalam menjalankan profesinya. Pola hubungan ini terekam dalam sistem peradilan Indonesia sebagai manifestasi pelaksanaan kekuasaan yudikatif. ${ }^{28}$

Sistem peradilan sebagai bentuk mekanisme penegakan hukum diisi oleh aktor-aktor penegak hukum terdiri dari polisi, jaksa, hakim kemudian advokat. Kuartet ini melalui sistem peradilan diharapkan dapat menghadirkan proses penegakan hukum yang berkeadilan sesuai dengan cita negara hukum. Polisi, jaksa dan hakim adalah bentuk representasi negara dalam sistem peradilan, sedangkan advokat bertindak mewakili masyarakat pencari keadilan dan diposisikan di luar sistem.

Secara historis peran advokat ada seiring perkembangan hukum dan masyarakat, hukum akan selalu ada selagi ada masyarakat dan masyarakat memerlukan hukum sekaligus menghendaki penegakan hukum. Kemudian negara sebagai wujud kekuasaan formal, bersama perangkat dan sistem hukumnya dipercayakan untuk melengkapi hukum yang tadi masih berupa kesadaran dan norma moral sehingga menjadi aturan atau norma hukum yang dapat ditegakkan (enforceable). Dalam negara modern ialah dalam bentuk trias politica negara menjalankan tugasnya.

Bersama tumbuhnya masyarakat dan negara, advokat tumbuh sebagai bagian penegakan hukum yang substansial yang mengunakan pendekatan langsung kepada kepentingan hukum dan keadilan masyarakat

${ }^{28}$ Ibid. 
banyak. Hal ini jelas berbeda dengan apa yang dilakukan negara yang bertumpu kekuasaan dengan pendekatan ketertiban umum (openbare order) dengan seperangkat aturan (rules) guna memberikan kepastian hukum. Sebagai pemegang mandat kekuasaan, negara demi ketertiban hukum lantas membentuk organ atau struktur penegak hukum (yudikatif) pelaksana sistem peradilan.

Disisi lain, advokat sebagai unsur independen, dalam arti tidak terikat pada struktur kekuasaan negara, menjalankan perannya baik di dalam maupun di luar pengadilan. Independensi profetik yang dimilikinya sungguh menjadi penjamin profesi ini dimata masyarakat pencari keadilan sekaligus dihadapan penguasa, dengan kepentingan utamanya yaitu memastikan keabsahan proses keadilan yang diselenggarakan negara pada setiap tahapan (legislasi, eksekusi dan yudikasi). Adapun setidaknya independensi profetik yang dimaksud ialah independensi etis dan independensi organisatoris.

Independensi etis, merupakan keadaan yang didasari oleh kesadaran akan moralitas yang disertai dengan semangat mencari keadilan dan kebenaran sebagai tujuan utamanya. Moralitas yang dijunjung tinggi adalah nilai-nilai kebaikan dengan kejujuran dan budi yang lurus bukan argumen-argumen pembenaran sebab keadilan diciptakan bagi semua (justitia voor eideren) yang diberlakukan secara imparsial dan nondiskriminasi. Sedangkan independensi organisatoris menekankan kemandirian organisasi berdiri dengan konsisten berhadapan dengan penguasa dan kekuasaan.

Dengan alasan kemandirian sebagai landasan dalam menjalankan proses penegakan hukum yang adil. Ditambah dengan kenyataan kemampuan negara/penguasa melakukan intervensi terhadap berjalannya proses yang adil (due proses of law), penguatan organisasi dalam segala aspek menjadi agenda sangat penting setidaknya dengan bersama dalam organisasi dapat mengimbangi kualitas intervensi yang ada. Apalagi hari ini tidak hanya penguasa yang mengintervensi proses hukum akan tetapi juga banyak pihak-pihak lain yang mencoba merecoki proses hukum tersebut, dan untuk ini dengan independensinya organisasi advokat harus bisa tetap berdiri tegak dan berkata tidak pada segala jenis intervensi.

Keberadaan UU advokat bagi kita pelaku profesi hendaknya musti disikapi dengan arif dalam mengartikulasikannya pada kenyataan tidak sekedar terkungkung pada batasan orang yang memberikan jasa hukum sesuai bunyi undang-undang. Ia selayaknya dibaca dalam lingkup yang lebih luas mengingat suatu yang officium nobile tidak sebatas kerangka sempit definisi yang diberikan undang-undang saja sehingga profesi tetap memiliki nilai dan peran menentukan dalam perubahan sosial berikutnya.

Nampak jelas bahwa advokat tidak termasuk dalam lingkup ketiga kekuasaan tersebut (eksekutif, legislative, dan yudikatif). Advokat sebagai penegak hukum menjalankan peran dan fungsinya secara mandiri untuk mewakili kepentingan masyarakat (klien) dan tidak terpengaruh kekuasaan negara (yudikatif dan eksekutif). Dalam mewakili kepentingan klien dan membela hak-hak hukum tersebut, cara berpikir advokat harus objektif menilainya berdasarkan keahlian yang dimiliki dan kode etik profesi. Untuk itu, dalam kode etik ditentukan adanya ketentuan advokat boleh menolak menangani perkara yang menurut keahliannya tidak ada dasar hukumnya, dilarang memberikan informasi yang menyesatkan dan menjanjikan kemenangan kepada klien. Disisi lain, advokat juga memiliki peran dalam proses kepailitan dalam kaitannya dengan Perseroan Terbatas (PT) diantaranya adalah peran kebebasan. Kebebasan tersebut dimak-sudkan agar advokat dapat bertindak luwes dalam menjalankan tugas. Dalam perkara pidana, sesuai dengan KUHAP advokat yang 
menerima kuasa kedudukannya sebagai penasehat hukum terdakwa. Sedangkan dalam perkara perdata kedudukannya menurut HIR/R.Bg. sebagai kuasa hukum. Sedangkan dalam membela perkara pidana di tingkat penyidikan sebagai penasehat baru bersikap aktif ketika mendampingi terdakwa di sidang pengadilan. Di persidangan dalam membela hak-hak terdakwa dapat mengajukan keberatan terhadap surat dakwaan, mengajukan pertanyaan terhadap para saksi, mengajukan saksi yang menguntungkan terdakwa (a de charge), dan mengajukan pembelaan. Sedangkan di persidangan perkara perdata sebagai kuasa hukum seorang advokat baik mewakili penggugat atau tergugat bersikap aktif, karena pihak berperkara dapat tidak menghadiri sidang, sehingga aktif mulai menyusun surat gugatan, jawab menjawab, pembuktian dan kesimpulan.

\section{PENUTUP}

Suatu perusahaan yang dinyatakan pailit pada saat ini akan mempunyai imbas dan pengaruh buruk bukan hanya kepada perusahaan itu saja melainkan berakibat global. Oleh karena itu, lembaga kepailitan merupakan salah satu kebutuhan pokok didalam aktivitas bisnis karena adanya ststus pailit merupakan salah satu sebab pelaku bisnis keluar dari pasar. Begitu memasuki pasar pelaku bisnis bermain didalam pasar. Apabila pelaku bisnis sudah tidak mampu lagi untuk bermain di arena pasar, maka dapat keluar dari pasar atau terpaksa atau bahkan dipaksa keluar dari pasar. Dalam hal seperti inilah kemudian lembaga kepailitan itu berperan.

Realisasi dan tindakan pemerintah untuk melindungi hak-hak pihak yang berkaitan dengan masalah kepailitan adalah merevisi Undang-Undang Kepailitan sebagaimana diatur dalam Staatsblaad Tahun 1905 No. 217 juncto Staatsblaad Tahun 1906 No. 348 menjadi Peraturan Pemerintah Pengganti Undang-Undang (Perpu) No. 1 Tahun 1998 tentang Perubahan Atas UndangUndang Kepailitan yang dikeluarkan pada tanggal 22 April 1998. Tanggal 9 September 1998 Perpu No. 1 Tahun 1998 disahkan menjadi Undang-undang No. 4 Tahun 1998 tentang Perubahan Atas Undang-undang Kepailitan menjadi Undang-Undang, akhirnya pada tanggal 18 Oktober 2004 UndangUndang No. 4 Tahun 1998 diganti menjadi Undang-Undang No. 37 Tahun 2004 tentang Kepailitan Dan Penundaan Kewajiban Pembayaran Utang.

Pengantian Undang-Undang No. 4 Tahun 1998 menjadi Undang-Undang No. 37 Tahun 2004 sangat penting, karena sudah dianggap tidak sesuai lagi dengan perkembangan jaman. Sebagai pengemban amanat rakyat. Presiden mempunyai kewajiban konstitusional untuk melaksanakan pembangunan nasional, salah satu bagian dari pembangunan nasional adalah pembangunan hokum nasional yang berorientasi kepada mewujudkan masyarakat adil dan makmur berdasarkan pancasila dan UUD 1945.

Salah satu produk hukum yang bertujuan untuk menjamin kepastian, ketertiban, penegakan dan perlindungan hukum yang berisi keadilan dan kebenarana yang diperlukan saat ini guna mendukung pembanguna perekonomian nasional adalah peraturan mengenai kepailitan dan penundaan kewajiban pembayaran utang. Tujuan utama dari perubahan yang dimaksud untuk memberikan keseimbangan antara kreditor dan debitor menghadapi masalah kepailitan, memberikan kepastian proses, baik menyangkut waktu, tata cara, tanggung jawab pengelolaan harta pailit dan memudahkan penyelesaian hutang piutang secara cepat, adil, terbuka dan efektif. Selain itu tujuan dari pada pengundangan Undang-Undang Kepailitan adalah untuk mewujudkan penyelesaian masalah utang piutang secara cepat, adil, terbuka dan efektif. 


\section{DAFTAR PUSTAKA}

\section{Buku :}

Asikin, Zainal. Hukum Kepailitan Dan Penundaan Kewajiban Pembayaran Utang Di Indonesia, Pustaka Reka Cipta, Bandung, 2013.

Dirdjosisworo, Soedjono. Bertrand Russell, Cita-Cita Politik, Armico, Bandung, 1983.

Harahap, M. Yahya. Beberapa Tinjauan Mengenai Sistim Peradilan dan Penyelesaian Sengketa, Cet. 1. Citra Aditya Bakti, Jakarta, 1997.

Hoff, Jerry. Undang-Undang Kepailitan Di Indonesia, Penterjernah Kartini MuIjadi, PT. Tatanusa, Jakarta, 2000.

Kansil, C.S.T dan Cristine S.T, Hukum Perusahaan Indonesia Bag 1, Pradnya Paramita, Jakarta, 2005.

Kusumah, Mulyana W. Perspektif, Teori dan Kebijaksanaan Hukum, Rajawali, Jakarta, 1986.

Rasjidi, Lili. dan Putra. I. B. Wiyasa, Hukum Sebagai Suatu Sistem, Remaja Rosdakarya, Bandung, 2005.

Reinhard, Anton. Masalah Hukum (dari Katalog Sampai Kwitansi), Cet. 1, Aksara Persada, Jakarta, 1985.

Sastrawidjaja, H. Man S. Hukum Kapailitan Dan Pendundaan Kewajiban Pembayaran Utang, PT. Alumni, Bandung, 2006.

Shubhan, M. Hadi. Hukum Kepailitan, Prinsip, Norma dan Praktik Di Pengadilan, Prenadamedia, Jakarta, 2008.

Sinaga, Syamsudin. Hukum Kepailitan Indonesia, Tianusa, Jakarta, 2012.

Sjahdeini, Sutan Remy. Hukum Kepailitan, Memahami Faillissemensverordening Juncto Undang-undang No. 4 Tahun 1998, PT. Pustaka Utama Grafiti, Jakarta, 1998.

Soemitro, Rony Hanitijo. Beberapa Masalah Dalam Studi Hukum Dan Masyarakat, Remadja Karya, Bandung, 1985.
Subekti, R. R. Tjitrosudibio, Kitab UndangUndang Hukum Perdata, PT. Pradnya Paramita, Jakarta, 2005.

Supramono, Gatot. Bagaimana Mendampingi Seseorang di Pengadilan: Dalam Perkara Pidana dan Perkara Perdata, Djambatan, Jakarta, 2008.

\section{Perundang-Undangan :}

Kitab Undang-Undang Hukum Perdata (Burgerlijk Wetboek Voor Indonesie), Staatsblad Tahun 1847 Nomor 23.

Undang-Undang Advokat, Undang-Undang No. 18 Tahun 2003 tentang Advokat Lembaran Negara Republik Indonesia Tahun 2003 Nomor 49, Tambahan Lembaran Negara Republik Indonesia Nomor 4288.

\section{Dokumen dan Makalah :}

Suparman, Eman. "Persepsi Tentang Keadilan Dan Budaya Hukum Dalam Penyelesaian Sengketa", Makalah Pada Seminar Nasional Tentang Pendayagunaan Sosiologi Hukum Dalam Masa Pembangunan Dan Restrukturisasi Global, Fakultas Hukum UNDIP, Semarang, 12-13 Nopember 1996.

Suyudi, Aria. Eryanto Nugroho, Herni Sri Nurbayanti, Kepailitan di Negara Pailit, Pusat Studi Hukum \& Kebijakan Indonesia, Jakarta, 2003.

Widjaya, Gunawan. "Risiko Hukum \& Bisnis Perusahaan Pailit", Majalah Forum Sahabat, 2000.

\section{Website :}

"Apa Itu Kepastian Hukum", http://yancearizona.wordpress.com, diakses tanggal 10 September 2017.

"Empat Kiat Jadi Advokat Kepailitan Yang Handal, Jika Tak Mau Dicurangi, Jangan Curangi Orang Lain", http://www.hukumonline. com/berita/ baca/lt5582549f59b6e/ empat- kiatjadi- advokat-kepailitan- yang- handal, diakses tanggal 10 September 2017. 
Jurnal AJUDIKASI Vol. 2 No. 1. Juni 2018, 89-115 